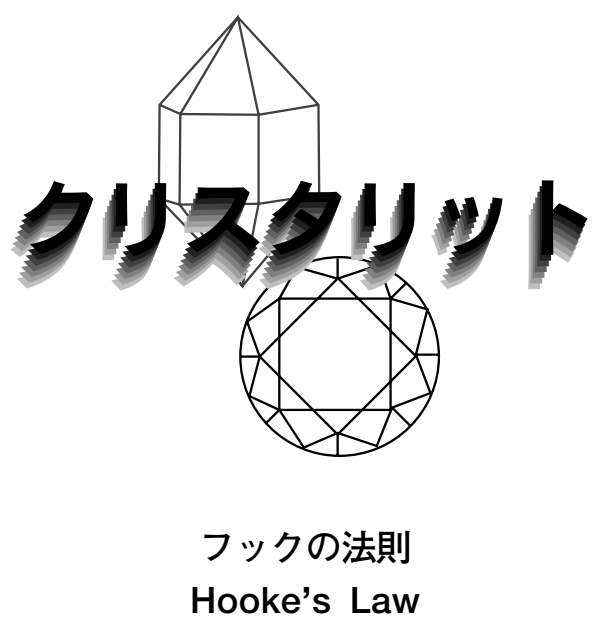

弾性体のひずみが応力に比例することをフックの法則 という. 応力が 1 軸方向にのみ存在する場合は, 応力 $\sigma$ と ひずみ $\varepsilon$ 関係はヤング率 $E$ を用いて $\varepsilon=\sigma / E$ と表され る. ここで, ヤング率 $E$ は等方弾性体の弾性定数を表して いる.ただし，一般的に物体に加えられる応力は 3 軸で考 えなければならない. また弾性体も等方的とは限らない. このとき, 応力とひずみの関係はテンソル式 $\varepsilon_{i j}=S_{i j k l} \sigma_{k l}$ $(k, l=1,2,3)$ で表される. ここで, 応力の係数 $S_{i j k l}$ は弾 性コンプライアンス定数と呼ばれ, 通常 $6 \times 6$ のマトリッ クスで表される. また, 逆に応力をひずみで表すときの係 数は弾性スティッフネス定数と呼ばれ, $C_{i j k l}=S_{i j k l} l^{-1}$ で表さ れる.すなわち, $\sigma_{i j}=C_{i j k l} \varepsilon_{k l}(k, l=1,2,3)$ の関係を示 す.ここで, $\varepsilon_{i j}$ と $\sigma_{i j}$ は 2 つの付文字, $S_{i j k l}$ と $C_{i j k l}$ は 4 つ の下付文字で表されているが，これらはそれぞれ 2 階と 4 階のテンソル量を示している.このようにテンソル式を用 いて表される応力とひずみの関係は一般化されたフック の法則と呼ばれる.

(株リガク X 線研究所 横山亮一)

\section{弾性コンプライアンス定数 Elastic Compliance Constants}

3 軸で応力を考えると, 一般化されたフックの法則に基 ついて, ひずみ $\varepsilon_{i j}$ と応力 $\sigma_{k l}$ の関係は弾性コンプライアン 又定数 $S_{i j k l}$ を用いて $\varepsilon_{i j}=S_{i j k l} \sigma_{k l}(k, l=1,2,3)$ と表される. すなわち, すべてのひずみ成分は応力の線形結合によって 表される.ここで, 弾性定数は 4 階のテンソル量で示され, $3^{4}=81$ 個の成分が存在する. また，ひずみと応力はそれぞ れ 2 階のテンソル量で示され, $3^{2}=9$ 個の成分が存在する. しかしながら, 応力, ひずみおよび弾性定数のテンソルの 対称性 $\left(\varepsilon_{i j}=\varepsilon_{j i}, \sigma_{i j}=\sigma_{j i}, S_{i j k l}=S_{k l i j}\right)$ を考えると, ひずみ と応力の独立な成分は 6 個に, 弾性定数は $6 \times 6$ の対称行 列の 21 個の独立な成分にそれぞれ縮小される.さらに, 弾 性定数の 21 個の独立な成分も結晶の対称性を考慮すると 0 になる成分が多く出てくる. 例えば，立方晶系の弾性コ ンプライアンス定数では, マトリックス表記 (例： $\varepsilon_{11} \rightarrow$ $\left.\varepsilon_{1}, S_{1111} \rightarrow S_{11}\right)$ で表すと, $S_{11}, S_{12}, S_{44}$ の 3 つの成分のみが 日本結晶学会誌 第 52 巻 第 2 号 (2010)
独立な值をもち，残りの成分はすべて0になる．したがっ て, 弾性定数の独立な成分は各結晶系によって異なり, 文 献などで与えられるのが一般的である.

(株りガク X 線研究所 横山亮一)

\section{アストロサイト \\ Astrocyte}

脳の中枢神経系は, 神経細胞のニューロンと神経細胞で はないグリア細胞で構成される.グリア細胞の一種である アストロサイトは, ニューロンの周囲にあってニューロン を養っていると考えられている. シナプス前ニューロンか ら放出されたグルタミン酸が, シナプス後ニューロンのグ ルタミン酸受容体に結合することで神経伝達が起こる. その際に, アストロサイトに存在するセリンラセマーゼに よって生産されたD-セリンが，グルタミン酸と同時に NMDA 受容体に結合するとシナプス後ニューロンはより 強く興奮し, 神経伝達は増大することが知られている.

(東邦大学理学部 後藤 勝)

\section{$\mathrm{H} / \mathrm{D}$ 交換率 \\ H/D Exchange Ratio}

中性子は水素原子によって強い非干渉性散乱を起こし， 回折測定のバックグラウンドが大きくなることが知られ ている. そこでタンパク質の中性子回折実験では, 試料に 含まれる水素原子を非干渉性散乱の小さな重水素原子 (水 素原子の $1 / 40$ 程度) に置換することが一般的である. 最 も簡便な方法は, 結晶化母液を重水で調製する方法で, 結 晶化自体を重水素化溶液で行うか, 結晶を重水素化母液に 浸漬する.この場合, 結晶中の溶媒 (水) とともに, タンパ ク質中の酸素や窒素原子に結合している水素も重水素に 置き換わる. 水素原子が重水素原子へ置換される割合 $(\mathrm{H} / \mathrm{D}$ 交換率) は水素原子の環境 (主鎖か側鎖か, 分子の内 部か外部か, 水素結合への関与, など）に大きく左右され る. H/D 交換率はほかのパラメータと合わせて, 精密化の 際に決定する.中性子とX線の同時精密化に用いられる プログラム (PHENIX や nCNS) はH/D 交換率決定に対応 している.

なお, 上記の置換法ではタンパク質中の水素原子の 7 割 以上を占める炭素原子に結合した水素原子を重水素原子 に置き換えることはできない. そこで, タンパク質を構成 するすべての水素原子を重水素原子に置き換えた完全重 水素化タンパク質を用いることによる, 回折データの向上 や必要結晶サイズの軽減が期待される. 完全重水素化タン パク質は発現する大腸菌を重水素化培地で培養したり, 試 験管内翻訳系を使ったタンパク質発現を重水素化環境下 で実施することにより，調製可能である。

(日本原子力研究開発機構 量子ビーム応用研究部門 玉田太郎) 


\section{短距離イオン性水素結合 Short Ionic Hydrogen Bond (SIHB)}

水素結合は静電相互作用の 1 つである. 水素結合を形成 する水素原子は電気陰性度の高いドナー原子 (水素供与原 子）に共有結合し，アクセプター(水素受容原子) と呼ば れる原子との間で, 弱い静電相互作用を生ずる. タンパク 質に見られる通常の水素結合では, ドナーとアクセプター の距離 (水素結合距離) は $2.8 \AA$ 程度であるが, その距離 が短く (2.6 ^以下) なると, 水素原子がドナーとアクセ プターの間を簡単に行き来できるようになり（エネルギー 障壁が低くなる), ドナーとアクセプターの中間に観測さ 机る「低障壁水素結合 (LBHB : Low Barrier Hydrogen Bond)」と言われる強い水素結合が形成される.ただし，ド ナーとアクセプターの距離が $2.6 \AA$ 以下なら LBHB が形 成されるとは限らず, 水素原子がドナーと通常の共有結合 距離で存在する場合もある.このような水素結合を短距離 イオン性水素結合 (SIHB : Short Ionic Hydrogen Bond) と呼ぶ. SIHB も通常の水素結合よりは強い水素結合では あるが, LBHB に比べると弱く, その構造的特徵と併せて LBHB と区別されている.

(日本原子力研究開発機構 量子ビーム応用研究部門 玉田太郎)

\section{高配向性熱分解グラファイト Highly Oriented Pyrolytic Graphite (HOPG)}

人造の単結晶ライクグラファイト. 天然単結晶グラファ イトは数ミリ以下の粒状でしか産出しないため, それ以上 の大きさの単結晶ライクグラファイトを作る方法として, ガス堆積結晶成長法と高分子グラファイト化法が考案さ
れた. ガス堆積結晶成長法は炭化水素ガスを熱分解して炭 素原子をチャンバー内で基板上に降り積もらせ, 結晶成長 させる方法であり, HOPG は, その方法の商品名のように なっている. 基板上に結晶成長開始点が多数できることか ら単結晶の集合体だ゙, 単結晶と同等の挙動や特性を示 す. 当初, 宇宙用の耐熱材料として開発されたといわれて おり,アメリカ国外へのもち出しが厳しく規制されてい た：そのため, フランス，ロシア，中国でも同じ製造方法 による生産が行われていた．高分子グラファイト化法は, 高分子フィルムを出発材料として単結晶ライクグラファ イトを製造する方法である。これらは主に，X線や中性子 線の波長フィルタとして用いられている.

(パナソニックプロダクションテクノロジー(秼) 西木直巳)

\section{ダブルベント形 (トロイダル形) グラファイト Double-Bent (Toroidal) Type Graphite}

X 線を回折・集光するためのグラファイト結晶. グラフ アイト結晶を曲面に成形し，それを3 個組み合わせて樽状 に配置し内面でX 線を回折させて集光する. 従来, X線を 集光によって強度アップする方法は低入射角での反射に よるものしかなかった. グラファイトはX 線分光精度は あまり高くないが積分強度を稼ぐことができるが, 結晶性 を保ったまま曲面を作ることができないという課題があ った. 高分子グラファイト化法によるグラファイト結晶の 製造方法ではダブルベンディングが可能となり, 銅やモリ ブデンなどの特性 X線の回折と集光が可能である. 回折 波長と同じ波長のX線で, 直接光と回折光を比較すると 200 倍程度の強度が得られた。

(パナソニックプロダクションテクノロジー(侏) 西木直巳） 